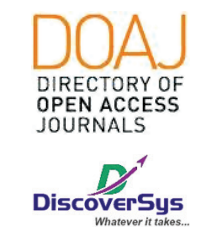

Published by DiscoverSys

\section{Hubungan indeks massa tubuh terhadap kadar gula darah puasa pengunjung lapangan Niti Mandala Renon bulan Juli Tahun 2018}

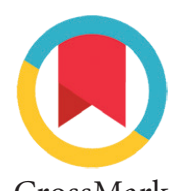

CrossMark

\author{
Dinda Yustisia Dewi, ${ }^{1 *}$ Anak Agung Ngurah Subawa, ${ }^{2}$ Ni Nyoman Mahartini ${ }^{2}$
}

\section{ABSTRACT}

Background: Diabetes Mellitus (DM) is one type of degenerative disease that increases annually in countries around the world. Overweight and obesity can be a risk factor for type 2 diabetes mellitus. The leading cause of obesity is the unbalanced energy between the calories consumed and the calories used.

Aim: This study aims to find the relationship between BMI with fasting blood glucose in Niti Mandala Renon field in July 2018.

Methods: The study used cross sectional analytic approach, with samples were Niti Mandala field visitors Renon July 2018. The total sample was determined by correlation coefficient formula single sample.

Results: Fasting blood glucose levels have an average level of $81.6 \mathrm{mg} / \mathrm{dl}$ and data are normally distributed ( $p>0.05$ ). There was a positive correlation between BMI with fasting blood glucose levels $(r=0.295 ; p=0.015)$.

Conclusion: There is a positive and significant weak correlation between BMI and fasting blood glucose levels of visitors to the Niti Mandala, Renon in July 2018.

Keywords: DM, IMT, obesity, fasting blood sugar

Cite This Article: Dewi, D.Y., Subawa, A.A.N., Mahartini, N.N. 2019. Hubungan indeks massa tubuh terhadap kadar gula darah puasa pengunjung lapangan Niti Mandala Renon bulan Juli Tahun 2018. Intisari Sains Medis 10(3): 711-714. D0I: 10.15562/ism.v10i3.503

ABSTRAK

Latar Belakang: Diabetes Melitus (DM) adalah salah satu jenis penyakit degenerative yang mengalami peningkatan setiap tahun di negara-negara seluruh dunia. Kelebihan berat tubuh dan obesitas dapat menjadi faktor resiko penyakit DM tipe 2. Penyebab utama obesitas adalah tidak seimbangnya energi antara kalori yang dikonsumsi dan kalori yang digunakan.

Tujuan: Penelitian ini bertujuan untuk mencari hubungan antara IMT dengan kadar gula darah puasa pengunjung lapangan Niti Mandala Renon bulan Juli tahun 2018.
Metode: Penelitian menggunakan metode cross sectional analytic, dengan sample adalah pengunjung lapangan Niti Mandala Renon Bulan Juli tahun 2018. Jumlah sample ditentukan dengan rumus koefisien korelasi sampel tunggal.

Hasil: Kadar gula darah puasa memiliki kadar rata-rata $81.6 \mathrm{mg} /$ dl dan data berdistribusi normal $(p>0,05)$. Terdapat korelasi positif antara IMT terhadap kadar gula darah puasa $(r=0,295 ; p=0,015)$.

Simpulan: terdapat hubungan lemah yang positif dan signifikan antara IMT dan kadar gula darah puasa pengunjung lapangan Niti Mandala Renon bulan Juli tahun 2018.
1Program Studi Pendidikan Dokter, Fakultas Kedokteran Universitas Udayana

2Departemen Patologi Klinik, Fakultas Kedokteran Universitas Udayana

${ }^{*}$ Correspondence to: Dinda Yustisia Dewi, Program Studi Pendidikan Dokter, Fakultas Kedokteran Universitas Udayana dindadits@gmail.com

Diterima: 12-04-2019

Disetujui: 09-09-2019

Diterbitkan: 01-12-2019

Kata kunci: DM, IMT, obesitas, gula darah puasa

Cite Pasal Ini: Dewi, D.Y., Subawa, A.A.N., Mahartini, N.N. 2019. Hubungan indeks massa tubuh terhadap kadar gula darah puasa pengunjung lapangan Niti Mandala Renon bulan Juli Tahun 2018. Intisari Sains Medis 10(3): 711-714. D0I: 10.15562/ism.v10i3.503

\title{
PENDAHULUAN
}

Diabetes Melitus (DM) adalah salah satu jenis penyakit degenerative yang mengalami peningkatan setiap tahun di negara-negara seluruh dunia. Diabetes melitus adalah penyakit gangguan metabolik kronis yang ditandai dengan hiperglikemia akibat defisiensi insulin yang bersifat absolut atau relative. Menurut data World Health Organization (WHO) tahun 2015 penyakit diabetes disebabkan oleh beberapa hal tetapi sejauh ini sebagian besar kasus diklasifikasikan sebagai diabetes tipe 1 dan diabetes tipe 2. Diabetes mellitus tipe 1 ditandai oleh kerusakan sel beta yang disebabkan oleh proses autoimun, biasanya menyebabkan defisiensi insulin absolut. ${ }^{1}$ Diabetes Melitus Tipe 2 disebabkan oleh kegagalan sekresi insulin dan atau kegagalan pada proses metabolismenya pada sel perifer.

Tahun 2015 prevalensi DM di dunia meningkat 4 kali lipat dari 108 juta jiwa di tahun 1980 menjadi 415 juta jiwa di tahun 2014. ${ }^{2}$ Diabetes dengan 
komplikasi menduduki peringkat ke-3 sebagai penyakit penyebab kematian di Indonesia. ${ }^{3}$ Angka kejadian DM mengalami peningkatan dari 1,1 \% di tahun 2007 dan meningkat menjadi 2,1 \% di tahun 2013 dari keseluruhan penduduk sebanyak 250 juta jiwa. ${ }^{4}$ Diperkirakan bahwa pada tahun 2030 prevalensi DM di Indonesia mencapai 21,3 juta orang. ${ }^{5}$ Proporsi penyebab kematian akibat Diabetes Melitus pada kelompok usia 45-54 tahun di daerah perkotaan menduduki peringkat ke-2 yaitu 14,7\%. dan daerah pedesaan, DM menduduki peringkat ke-6 yaitu $5,8 \%{ }^{6}$

Faktor resiko diabetes dapat dikelompokkan menjadi 2 yaitu faktor resiko yang tidak dapat dimodifikasi dan yang dapat dimodifikasi. Faktor resiko yang tidak dapat dimodifikasi antara lain adalah suku, ras, etnis, genetic, umur, jenis kelamin, riwayat keluarga dengan diabetes melitus, serta riwayat lahir dengan berat badan lahir rendah. Faktor yang dapat dimodifikasi antara lain adalah pola hidup yang kurang sehat seperti kurangnya aktifitas fisik, pola makan yang kurang baik, obesitas abdominal/sentral, dislipidemia, hipertensi, riwayat toleransi glukosa terganggu, diet tidak seimbang, gula darah puasa terganggu, dan merokok. ${ }^{4}$

Dalam sepuluh tahun terakhir, obesitas menjadi masalah global. ${ }^{7}$ Pada tahun 2014 terdapat lebih dari 1,9 milyar orang dewasa diatas 18 tahun mengalami kelebihan berat tubuh dan lebih dari 600 juta orang mengalami obesitas. ${ }^{7}$ Kelebihan berat tubuh dan obesitas dapat menjadi faktor resiko penyakit karena gangguan metabolik seperti, penyakit jantung koroner, stroke iskemia dan diabetes mellitus tipe $2 .^{7}$ Penyebab utama obesitas karena tidak seimbangnya energi antara kalori yang dikonsumsi dan kalori yang digunakan. Penyebab ketidakseimbangan dapat disebabkan karena peningkatan asupan makanan berenergi dengan kandungan lemak yang tinggi dan penurunan aktivitas fisik karena meningkatnya pola hidup yang menetap dari berbagai bentuk pekerjaan,

\section{Tabel 1 Karakteristik subyek penelitian}

\begin{tabular}{lcc}
\hline Variabel & N & $\%$ \\
\hline Jenis Kelamin & & \\
$\quad$ Laki-laki & 33 & 51 \\
$\quad$ Perempuan & 34 & 49 \\
Usia & & \\
$\quad \leq 45$ tahun & 26 & 39 \\
$>45$ tahun & 41 & 61 \\
Tingkat Pendidikan & & \\
$\quad$ Rendah & 9 & 13 \\
$\quad$ Menengah & 12 & 18 \\
Tinggi & 46 & 69 \\
\hline
\end{tabular}

perubahan mode transportasi, dan peningkatan urbanisasi. ${ }^{7}$ Penegakan diagnosis Obesitas merujuk pada Indeks Massa Tubuh. Ini didefinisikan sebagai berat dalam kilogram dibagi dengan kuadrat tinggi dalam meter $(\mathrm{kg} / \mathrm{m} 2)$. Angka indeks massa tubuh yang mencapai $\geq 30.00$ dapat dikategorikan obesitas. $^{8}$

\section{METODE}

Penelitian analitik deskriptif ini dilakukan sekali waktu dan pada saat yang bersamaan tanpa dilakukan dengan follow up. Penelitian dilakukan di Lapangan Niti Mandala Renon pada bulan Juli tahun 2018 hingga jumlah sampel terpenuhi. Populasi target dari penelitian ini adalah pengunjung lapangan Niti Mandala Renon bulan Juli tahun 2018. Teknik sampling yang digunakan adalah two stage cluster random sampling. Kriteria Inklusi penelitian ini anatara lain bersedia mengikuti penelitian, berusia 17-40 tahun, bersedia diukur indeks massa tubuh, bersedia diukur kadar gula darah puasa, telah melakukan puasa selama 8 jam dan dalam keadaan sehat. Pengukuran dilakukan dengan menggunakan timbangan digital dan meteran tinggi badan untuk mencari Indeks Massa Tubuh. Glukometer digunakan untuk mencari kadar gula darah puasa subyek. Hasil dari pengukuran keduanya diolah dan dibandingkan untuk membut kesimpulan. Semua prosedur dilakukan setelah subyek menandatangani formulir informed consent. Pengolahan data dari penelitian ini akan dilakukan menggunakan aplikasi SPSS. Analisis data dilakukan dengan menggunakan uji normalitas Shapiro-Wilk untuk sampel yang berjumlah kecil. Hubungan antar data yang berdistribusi normal akan dilakukan dengan metode uji korelasi Pearson.

\section{HASIL}

Berdasarkan perhitungan korelasi analitik menggunakan rumus koefisien korelasi tunggal, didapatkan jumlah sampel minimal untuk penelitian ini adalah 30 subyek, dimana subyek yang mengikuti penelitian adalah 67 orang. Dari 67 subyek terdapat 33 orang (51\%) laki-laki dan 34 orang (49\%) perempuan. Terdapat 26 subyek (39\%) yang berusia di bawah 45 tahun dan 41 subyek (61\%) berusia diatas 45 tahun, dengan umur terendah 17 tahun dan umur tertinggi 63 tahun. Tingkat pendidikan subyek dalam penelitian ini dikelompokkan menjadi 3 antara lain tingkat pendidikan rendah, menengah, dan tinggi. Terdapat 9 subyek (13\%) dengan tingkat pendidikan rendah, 12 subyek (18\%) dengan tingkat pendidikan menengah, dan 46 subyek (69\%) dengan tingkat pendidikan 
Tabel 2 Status gizi (Nilai IMT)

\begin{tabular}{lcccc}
\hline & & & \multicolumn{2}{c}{ IMT (kg/m2) } \\
\cline { 4 - 5 } Status Gizi & N & \% & Mean & Median \\
\hline Berat badan kurang & 2 & 3 & & \\
Normal & 31 & 46 & & 25.01 \\
Berat badan lebih & 28 & 42 & 25.12 & \\
Obesitas I & 5 & 7 & & \\
Obesitas II & 1 & 1 & & \\
\hline
\end{tabular}

Tabel 3 Kadar gula darah puasa

\begin{tabular}{lcccc}
\hline Kadar Gula Darah & N & \% & Mean & Median \\
\hline Bukan DM & 59 & 88,5 & 81.6 & 81 \\
GDPT & 7 & 10,01 & & \\
DM & 1 & 1,49 & & \\
\hline
\end{tabular}

tinggi. Tingkat pendidikan paling rendah adalah tidak menempuh bangku sekolah, dan tingkat pendidikan paling tinggi adalah pendidikan pasca sarjana.

Hasil penelitian besar IMT menunjukkan besar rata-rata IMT dari 67 subyek adalah $21.25 \mathrm{~kg} /$ m2. Dengan nilai tengah IMT adalah $25.01 \mathrm{~kg} /$ m2. Berdasarkan hasil pengukuran terdapat 2 subyek (3\%) dengan kategori berat badan kurang, 31 subyek (46\%) dengan kategori berat badan normal, 28 subyek (42\%) dengan kategori berat badan lebih, 5 subyek (7\%) dengan kategori obesitas I dan 1 subyek (1\%) dikategorikan sebagai obesitas II.

Kadar gula darah puasa subyek berdasarkan penelitian yang dilakukan memiliki kadar rata-rata $81.6 \mathrm{mg} / \mathrm{dl}$ dengan nilai tengah kadar gula darah puasa $81 \mathrm{mg} / \mathrm{dl}$ serta nilai kadar gula darah yang paling sering muncul dalam penelitian ini adalah $82 \mathrm{mg} / \mathrm{dl}$. Terdapat 59 orang $(88,5 \%)$ subyek yang dikategorikan bukan DM, 7 orang $(10,01 \%)$ dengan kadar gula darah puasa terganggu, dan 1 orang (1,49\%) dengan DM.

Data yang diperoleh berikutnya diolah dengan menggunakan metode uji normalitas ShapiroWilk dengan hasil data berdistribusi normal sesuai dengan nilai kolom Sig. seluruhnya diatas 0.05 . Karena data berdistribusi normal, uji korelasi yang digunakan dalam penelitian ini adalah uji korelasi Pearson. Terdapat nilai $r$ antara IMT terhadap gula darah puasa sebesar 0,295 yang berarti terdapat korelasi positif antara IMT terhadap kadar gula darah puasa. Nilai $r$ antara IMT terhadap gula darah puasa sebesar 0,295 menunjukkan korelasi lemah. Nilai sig. (2 tailed) antara IMT terhadap kadar gula darah puasa adalah 0,015 yang dalam hal ini kurang dari 0,05, maka hasil korelasi antara IMT dan kadar gula darah puasa adalah signifikan.

\section{DISKUSI}

Pada penelitian ini ditemukan subyek dengan gula darah puasa terganggu sebanyak 7 orang 2 perempuan dan 5 laki-laki. Ditemukan subyek dengan DM sebanyak 1 orang laki-laki berumur diatas 45 tahun. Hal ini menguatkan teori faktor resiko diabetes dimana faktor resiko DM mengalami peningkatan pada usia diatas 45 tahun. ${ }^{9}$ Pada usia diatas 45 tahun kondisi tubuh manusia mengalami proses degenerasi berupa penurunan fungsi fisiologis yang akan mempengaruhi kerja sel-sel perifer pembuluh darah dalam transport glukosa ke sel-sel tubuh. Terdapat beberapa faktor risiko mayor yang berpengaruh terhadap DM tipe 2 antara lain adalah usia lebih dari 45 tahun, riwayat keluarga dengan DM, Ras, riwayat toleransi gula darah terganggu, riwayat gula darah puasa terganggu, hipertensi, dislipidemia dan riwayat diabetes gestasional atau melahirkan bayi dengan berat badan lahir lebih dari 4 kg. ${ }^{9}$

Hasil penelitian besar IMT menunjukkan besar rata-rata IMT dari 67 subyek adalah $21.25 \mathrm{~kg} / \mathrm{m} 2$. Dengan nilai tengah IMT adalah $25.01 \mathrm{~kg} / \mathrm{m} 2$. Nilai IMT yang paling sering muncul tidak dapat ditentukan karena hasil pengukuran berbeda-beda setiap subyek. Nilai IMT ditentukan dengan hasil bagi antara berat badan dalam kilogram terhadap kuadrat tinggi badan dalam meter, maka dari itu nilai IMT tidak dapat memberi informasi seputar nilai kadar lemak yang ada di dalam tubuh. ${ }^{7}$ IMT tidak dapat dijadikan pedoman untuk menyatakan kadar lemak yang ada di dalam tubuh karena diperlukan pengukuran yang lebih spesifik berupa pengukuran lingkar pinggang dan analisis kadar lemak menggunakan alat Bioelectrical Impedance Analysis (BIA). ${ }^{10}$

Berdasarkan hasil pengukuran IMT terdapat 2 subyek dengan kategori berat badan kurang, 31 subyek dengan kategori berat badan normal, 28 subyek dengan kategori berat badan lebih, 5 subyek dengan kategori obesitas I dan 1 subyek dikategorikan sebagai obesitas II. Tingkat pendidikan dalam penelitian ini tidak dapat memberikan informasi yang berkaitan dengan IMT karena tidak memberikan informasi terkait taraf kesejahteraan subyek.

Berdasarkan hasil pengukuran kadar gula darah puasa subyek memiliki kadar rata-rata $81.6 \mathrm{mg} /$ dl dengan nilai tengah kadar gula darah puasa $81 \mathrm{mg} / \mathrm{dl}$ serta nilai kadar gula darah yang paling sering muncul dalam penelitian ini adalah $82 \mathrm{mg} /$ dl. Terdapat 59 orang subyek yang dikategorikan bukan DM, 7 orang dengan kadar gula darah puasa terganggu, dan 1 orang dengan DM. Seluruh hasil pengukuran dilakukan setelah subyek melakukan puasa selama 8 jam. ${ }^{11}$ 
Berdasarkan penelitian serupa terdapat hubungan yang tidak signifikan antara IMT dan kadar gula darah puasa. $^{12}$ Perbedaan antara penelitian ini dipengaruhi oleh perbedaan keragaman sampel dan perubahan jumlah sampel. Selain itu terdapat beberapa kemungkinan lain seperti metode pengambilan sampel darah dan bias dalam pengolahan data. Terdapat pula hubungan yang signifikan pada penelitian antara indeks massa tubuh terhadap kadar gula darah puasa lansia kota semarang tahun 2014 dengan (r) sebesar 0,614 dan nilai signifikansi ( $\alpha$ ) sebesar $0,034 .{ }^{13}$ Meski hasilnya sama-sama signifikan namun tetap terdapat perbedaan dari penelitian ini yakni tingkat signifikansi lebih besar karena menggunakan sampel yang lebih spesifik dan sampel memiliki faktor resiko yang lebih banyak mengingat usia sampel yang digunakan adalah diatas 45 tahun. ${ }^{13,14}$

Kendala dalam penelitian ini adalah kesulitan dalam mencari subyek penelitian yang disiplin secara kriteria inklusi yang dalam hal ini telah puasa selama 8 jam dan bersedia menjadi subyek penelitian. Terdapat pengunjung yang tidak bersedia menjadi subyek penelitian karena merasa sehat dan merasa tidak memerlukan tes kadar gula darah puasa. Maka dari itu diperlukan adanya edukasi lebih lanjut berupa penyuluhan dan promosi kesehatan kepada masyarakat. ${ }^{15}$

\section{SIMPULAN}

Terdapat sebanyak 3\% pengunjung dengan kategori berat badan kurang, $46 \%$ pengunjung dengan kategori berat badan normal, $42 \%$ pengunjung dengan kategori berat badan lebih, $7 \%$ pengunjung dengan kategori obesitas I dan $1 \%$ pengunjung dikategorikan sebagai obesitas II. Terdapat $88,5 \%$ orang pengunjung yang dikategorikan bukan DM, 10,01\% orang dengan kadar gula darah puasa terganggu, dan 1,49\% orang dengan DM. Hasil analisis data menunjukkan terdapat hubungan lemah yang positif dan signifikan antara IMT dan kadar gula darah puasa pengunjung lapangan Niti Mandala Renon bulan Juli tahun 2018.

\section{DAFTAR PUSTAKA}

1. Kumar, P.J. and Clark, M. 2002. Textbook of Clinical Medicine. 8th Edition, Saunders, London.

2. IDF. Diabetes Atlas (7th Edition). Brussels: International Diabetes Federation, 2015.

3. Kementrian Kesehatan Indonesia. 2014. Indonesia Sample Registration System - Deaths 2014.

4. Depkes RI. 2013. Riset Kesehatan Dasar (Riskesdas) 2013. Jakarta: Badan Penelitian dan Pengembangan Kesehatan.

5. Peyrot $\mathrm{M}$ et al. Diabetes care 2005; 28: 2673-2679

6. Depkes RI. 2007. Riset Kesehatan Dasar (Riskesdas) 2007. Jakarta: Badan Penelitian dan Pengembangan Kesehatan.

7. WHO. 2015. Diabetes Melitus. WHO News: Fact Sheets. Diakses dari: http://www.who.int/mediacentre/factsheets/ fs138/en/ pada tanggal 3 Januari 2018.

8. WHO. 2011 . Obesity and overweight. Geneva: World Health Organization.

9. American Diabetes Association. Classification and diagnosis of diabetes. Diabetes Care. 2015;38(suppl):S8-S16.

10. Mialich MS, Maria J, Sicchieri JM, Junior AJ. Analysis of body composition : A Critical review of the use of bioelectrical impedance analysis. International journal of clinical nutrition 2, no. 1(2014): 1-10.

11. Artha IMJR, Bhargah A, Dharmawan NK, Pande UW, Triyana KA, Mahariski PA, Yuwono J, Bhargah V, Prabawa IPY, Manuaba IBAP, Rina IK. High level of individual lipid profile and lipid ratio as a predictive marker of poor glycemic control in type- 2 diabetes mellitus. Vasc Health Risk Manag. 2019;15:149-157

12. Ari M, Ernalia Y, Rosdiana D. Hubungan IMT Terhadap Kadar Gula Darah Puasa Pada Pegawai Sekretariat Daerah Provinsi Riau. Jurnal Online Mahasiswa Riau. Vol 1. No 2. 2014

13. Dian, Y. Hubungan Indeks Massa Tubuh Terhadap Kadar Gula Darah Puasa Lansia Kota Semarang Tahun 2014. Universitas Negeri Semarang Scientific Journal. 2015.

14. Wulandari PDA, Wirata G, Putri CWS. Hubungan Antara Asupan Energi, Asupan Protein Dan Aktivitas Fisik Terhadap Status Gizi Penduduk Lanjut Usia Di Wilayah Kerja Upt Kesmas Blahbatuh II, Kecamatan Blahbatuh, Kabupaten Gianyar. E-Jurnal Medika Udayana, 2015; 4(7).

15. Kadek Dwi Pradnya Andrastea, I Nyoman Mangku Karmaya, I Nyoman Gede Wardana. Hubungan indeks massa tubuh dengan tingkat kebugaran kardiovaskular pada mahasiswi Program Studi Pendidikan Dokter, Fakultas Kedokteran Universitas Udayana usia 18-21 tahun. Bali Anatomy Journal 2018; 1(2): 30-34.

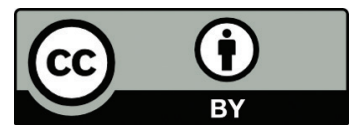

This work is licensed under a Creative Commons Attribution 